EESTI NSV TEADUSTE AKADẼEMIA TOIMETISED. 22. KOIDE

KEEMIA * GEOLOOGIA. 1973, NR. 1

ИЗВЕСТИЯ АКАДЕМИИ НАУК ЭСТОНСКОИ ССР. ТОМ 22 ХИМИЯ - ГЕОЛОГИЯ. 1973, 스 1

УдК $551.332 .212(474.2)$

A. PAУKAC

\title{
О ГЕНЕЗИСЕ МОРЕН ЭСТОНИИ
}

Благодаря исследованиям Ф. Шмидта (Schmidt, 1871 и др.) и К. Гревингка (Grewingk, 1879 и др.) уже в семидесятых годах прошлого века прочно утвердилось мнение о крупных материковых оледенениях на территории Әстонии, во время которых сформировались разнообразные гляцигенные формы рельефа и отложения.

Как известно, на протяжении последних лет теория покровных оледенений подвергалась острой критике со стороны приверженцев концепции гляциомаринизма. Сторонники этой концепции либо полностью отрицают возможность существования обширных континентальных ледниковых покровов, либо признают ее лишь в ограниченных масштабах.

Наиболее глубоко идеи гляциомаринистов изложены в работах И. Пидопличко $(1946,1951,1954,1956,1963)$. Он считает, что морены равнин Европы не отложены ледниками, а имеют самое разнообразное происхождение: в Приуралье и предгорьях Скандинавии это главным образом пролювий, в Прибалтике и на крайнем севере Европейской части СССР - прибрежное морское образование, в пределах днепровского ледникового языка - аллювиально-пролювиальное образование (Пидопличко, 1956, с. 246). В качестве отложений прибрежного моря морены или отдельные моренные горизонты Прибалтики рассматриваются и в работах ряда других исследователей (Афанасьев, 1967, 1968; Данилов и др., 1968 и др.).

Морской генезис приписывается гляциомаринистами также характерным гляцигенным формам рельефа. Конечные морены, широко распространенные в Прибалтийских странах, по их мнению представляют не что иное, как береговые валы, свидетельствующие о длительной стабилизации очертаний древнебалтийского бассейна и позволяющие проследить этапы сокращения его размеров. Прибрежными образованиями типа береговых валов считаются также друмлины.

Более разнообразным представляется гляциомаринистам генезис озов. Например, по мнению И. Пидопличко $(1956$, с. 256$)$, часть из них представляет береговые валы, другие - подводные образования типа кос, третьи - дельтовые образования и т. д. Камы наиболее часто рассматриваются как эрозионно-абразионные «останцовые» образования древнеморских террас.

Необходимо отметить, что в большинстве гляциомаринистских работ вопросы морфогенеза или вообще не рассматриваются, или затрагиваются очень поверхностно. Например, В. Чувардинский (1967), рассматривая образование валунных отложений и рельефа на Кольском полуострове, вынужден признать, что вопросы формирования озов и

5 ENSV TA Tolmetised K* G-1 1973 
камов остаются им не выясненными. Это и понятно, так как именно происхождение гляцигенных форм рельефа труднее всего объяснить с гляциомаринистских позиций.

Выводы о морском происхождении форм рельефа и отложений наиболее часто делаются на основании изучения отдельных показателей состава и текстур валунных суглинков (морен), причем полученные аналитические данные интерпретируются довольно произвольно. Разрезы плейстоценовых отложений, как известно, характеризуются большой сложностью строения. Здесь перемежаются ледниковые, водно-ледниковые, морские и другие типы отложений. Гляциомаринисты, исходя из своих теоретических предубеждений, рассматривают все указанные образования как отложения мелководного моря, часто даже не пытаясь выделить среди них отдельные генетические типы. Поэтому приводимые в работах гляциомаринистов «свсдные данные» о содержании в валунных суглинках (моренах) фауны и аутигенных новообразований лишены необходимой конкретности, но в то же время «достаточны», чтобы служить поводом для искаженных или неверных истолкований.

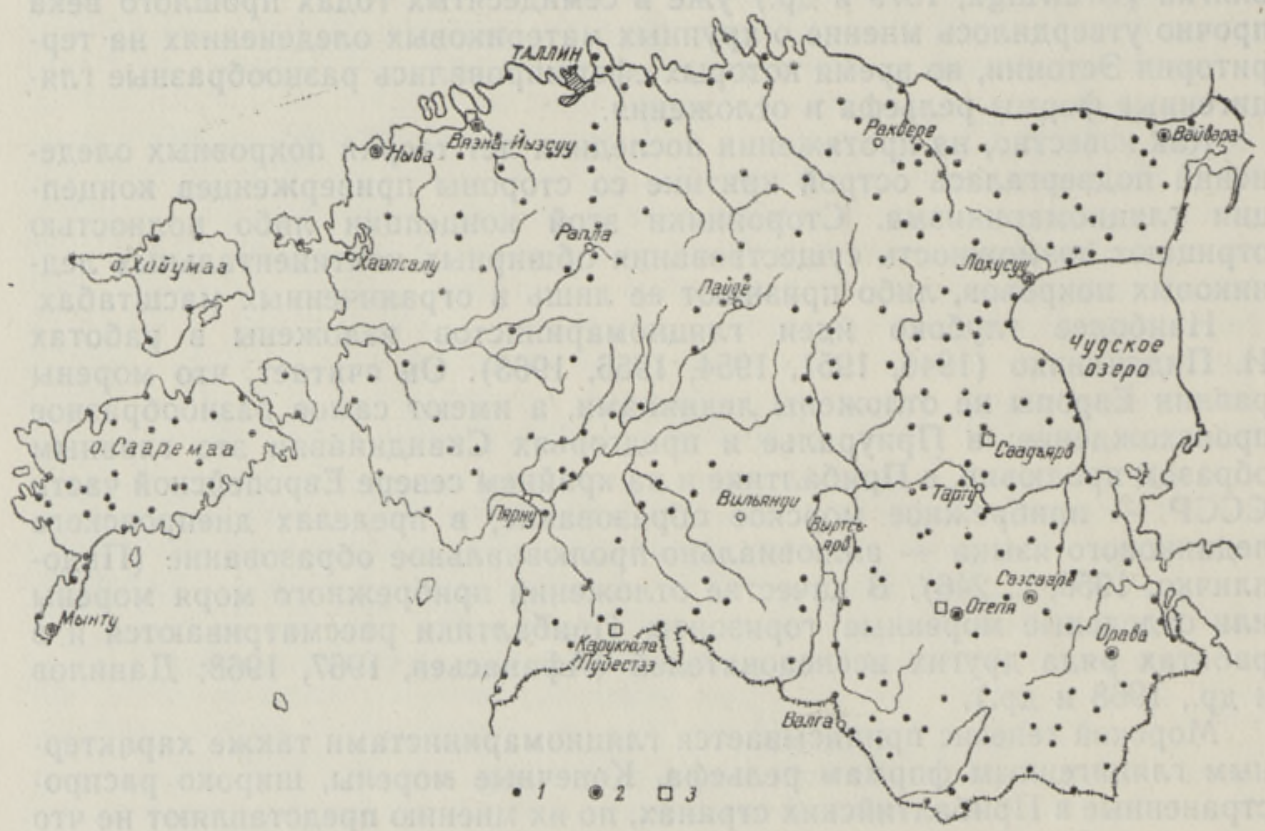

Рис. 1. Схема расположения изученных местонахождений и скважин.

1 - изученные обнажения или шурфы; 2 - места нахождения фауны; 3 - опробованные скважины.

Ввиду неоднократно предпринимавшихся попыток перенесения гляциомаринистской концепции также на территорию Эстонии, автором были проведены специальные комплексные исследования генезиса распространенных в республике морен. Частично эти работы были выполнены в содружестве с кафедрой криолитологии и гляциологии Московского государственного университета. Многочисленные палеонтологические, геохимические, структурно-текстурные, литолого-минералогические и геоморфологические исследования подтверждают сложившиеся ранее представления о ледниковом, преимущественно субаэральном генезисе эстонских морен. 
Наиболее веским аргументом для заключения о неледниковом субаквальном генезисе морен обычно считают наличие морской фауны в этих отложениях. Нами детальнс изучено и опробовано около 400 обнажений морен Әстонии (рис. 1) и просмотрено большое количество кернов буровых скважин. Лишь в трех местонахождениях низменной части Әстонии (Мынту, Вяэна, Ныва) в моренах были обнаружены отдельные мор. скпе субфоссильные моллюски (всего 2 экз. Portlandia arctica Gray и 1 экз. Cyprina islandica) плохой сохранности, которые явно переотложены из более древних морских отложений. В моренах возвышенной части республики местами (близ Отепя и Орава) обнаружены отдельные пресноводные моллюски (Pisidium sp.) и осколки речной раковины (Unio sp.).

Морские микроорганизмы в моренах Әстонии тоже очень редки. Микропалеонтологическому исследованию на диатомовые водоросли, фораминиферы, остракоды и спикулы губок подвергались отложения из ряда глубоких буровых скважин, вскрывающих несколько горизонтов морен (Карукюла, Пуйестээ, Отепя, Саадъярв, Вяэна-Йэсуу), и ряда обнажений, покрываюших более или менее равномерной сетью всю территорию республики. За исключением скв. Вяэна-Иыэсуу, диатомовые водоросли, фораминиферы, остракоды и спикулы губок или совершенно не были обнаружены (в отложениях из скважин Пуйестээ и Карукюла), или они встречались в виде единичных форм и фрагментов. Так, в обнажении поздневалдайской морены близ Лохусуу было обнаружено пять экземпляров фораминифер (Buccella frigida (Cushman) - 1, Elphidium subclavatum Gudina - 3, Protelphidium orbiculare (Brady) - 1) и в обнажении Саэсааре - один экземпляр Buccella frigida. По данным Б. Л. Афанасьева (1968), микрофауна найдена также в желтовато-серой морене последнего оледенения у подножья Вайвараских Синих гор.

В коричневой морене днепровского (?) оледенения, вскрытой в скв. Саадъярв, встречено несколько створок остракод неопределенного возраста ( 3 экз. Limnocythere sp., 7 экз. Candona sp., 2 обломанные створки Eucypris sp. и 2 створки, родовая принадлежность которых неясна).

Отдельные остракоды были обнаружены также в керне скв. Отепя. Так, на глубине 77,5 м была найдена одна левая створка Limnocythere sp. и несколько створок, напоминающих остракоды рода Candona; на глубине 86,0 м одна левая створка Limnocythere sp., две обломанные створки Candona sp. и одна обломанная створка Eucypris (?); на глубине 87,0 модна передняя часть правой створки Limnocythere sp., напоминающая Limnocythere difluxilis Jasu и две неопределенные формы. Фораминиферы и диатомовые встречены не были.

Всего по скв. Пуйестээ было просмотрено 43 образца, по скв. Отепя - 49, по скв. Саадъярв - 15 и по скв. Карукюла -12 образцов. Незакономерное и редкое распространение фауны, наличие обломанных и обтертых створок, а также присутствие наряду с четвертичными формами палеозойских явно свидетельствует о переотложении этой фауны.

В большем количестве микрофауна установлена лишь в узкой предглинтовой полосе, которая еще в недавнем прошлом и, по всей вероятности, также в межледниковые и межстадиальные этапы была занята морем или крупными озерно-ледниковыми бассейнами. Примером сказанного может служить скв. Вяэна-Иыэсуу (см. Раукас, Лийвранд, 1971). Но и здесь содержание фораминифер (обычно не более 9 экз. на 100 г породы) и диатомовых в моренах значительно беднее, чем в межморенной алевритовой глине. В ряде образцов они совершенно отсутствуют. Явная приуроченность фораминифер (до 6185 экз. на 100 г породы) и диатомовых к межморенному прослою говорит о том, что микрофауна и в моренах этого разреза по крайней мере частично переотложена со дна 
котловины Финского залива, где и в прошлом неоднократно существовали морские условия.

Геохимические исследования указывают на сравнительно низкую степень засоленности эстонских морен (порядка 30-40 мг.экв. на 100 г породы), что объясняется гидрослюдистым составом мелкозема морен. Обнаружены также весьма большие колебания состава водной вытяжки как по разрезам, так и по отдельным районам территории. Заслуживает внимания факт, что все изученные образцы имеют низкий (обычно менее $0,5)$ коэффициент щелочности и относительно высокое содержание калия, что также указывает на континентальные условия осадконакопления. В верхней части отдельных разрезов обнаружено несколько повышенное содержание аниона хлора, а также катионов натрия и калия, что, вероятно, обусловлено проникновением морской воды в ранее отложенную морену, поскольку аналогичные данные по составу поглощенного комплекса ленточных глин низменной части республики объяснимы именно влиянием соленых вод более поздних трансгрессий Балтийского бассейна (Пиррус, 1968).

О преимущественно континентальном ледниковом происхождении морен Эстонии говорит еще целый набор следующих литологических показателей: тесность связи их вещественного состава с составом подстилающих коренных пород; слабая отсортированность; отсутствие аутигенных новообразований морского происхождения; плохая окатанность обломков, несколько улучшающаяся в южном и юго-восточном направлении, т. е. в сторону предполагаемого движения материкового льда (Раукас, 1962); веерообразность конфигурации конусов разноса руководящих валунов с вершинами конусов, приуроченными к зоне наибольшей экзарации на южном крае Балтийского щита (Вийдинг, 1957; Раукас, 1963); относительно большое содержание глинистых частиц и высокая уплотненность (Martin, 1967; Nugis, 1962) морен, обусловленная динамическим виздействием движущегося льда.

U континентальном генезисе морен Әстонии говорят также их текстурные особ́енности. Об этом свидетельствует прежде всего ориентировка обломочного материала (включая как крупные валуны, так и частицы мелкозема) по направлению перемещения масс льда и притом в положении, близком к горизонтальному (Raukas, 1961; Раукас, 1962; Гайгалас и др., 1967). При отложении материала сходного облика в субаквальных условиях (напр., в морских бассейнах) картина распределения облимочного материала была бы иной - более утолщенные части валунов и галек были бы направлены книзу (Рухина, 1960; Лаврушин, 1969; Серебрянный, Раукас, 1970).

Морены на территории Эстонии обычно являются массивными породами без признаков слоистости и слоеватости. Слоистость в моренах наблюдается довольно редко и притом в основном или в низах, или в верхах разрезов (рис. 2). Обнаруживается она лишь в хорошо очищенных больших обнажениях, проявляясь в чередовании тонких слоев морены с прослойками песка или глины, а также в переслаивании слоев морены с разной окраской и различным гранулометрическим составом. Встречающиеся местами в морене более мощные накопления песчаноглинистого или гравийно-галечного материала имеют форму неправильных гнезд или линз и даже на близких расстояниях друг от друга расположены на различных гипсометрических уровнях. Они быстро выклиниваются (рис. 3). В ряде мест обнаружены ледниковые отторженцы (Jaansoon-Orviku, 1926; Orviku, 1930) и гляциодислокации ложа (рис. 4) (Orviku, 1936; Heinsalu, 1970). 


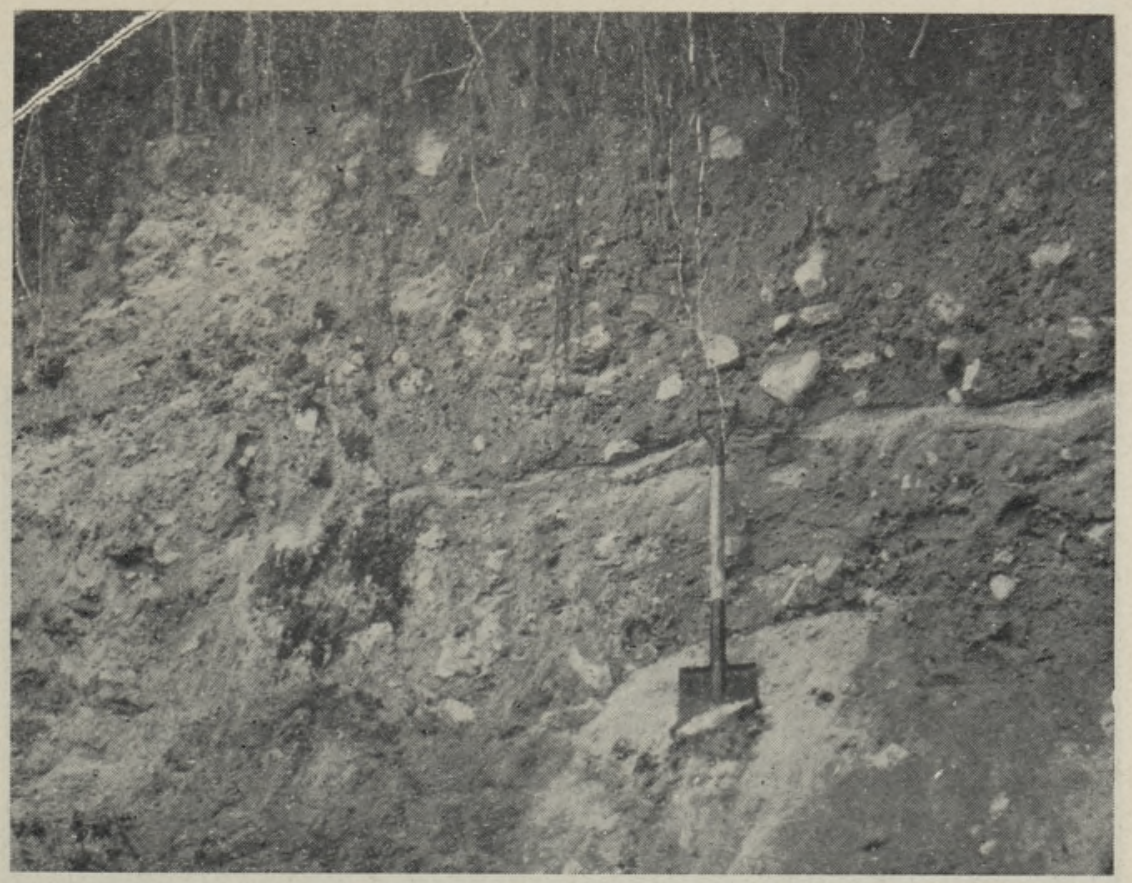

Рис. 2. Слегка рассланцованная морена в Сидорковичи. Наблюдаются маломощные прослои песка, обнаруживающие следы растаскивания и ледникового напора.

Фото А. Мийдела.

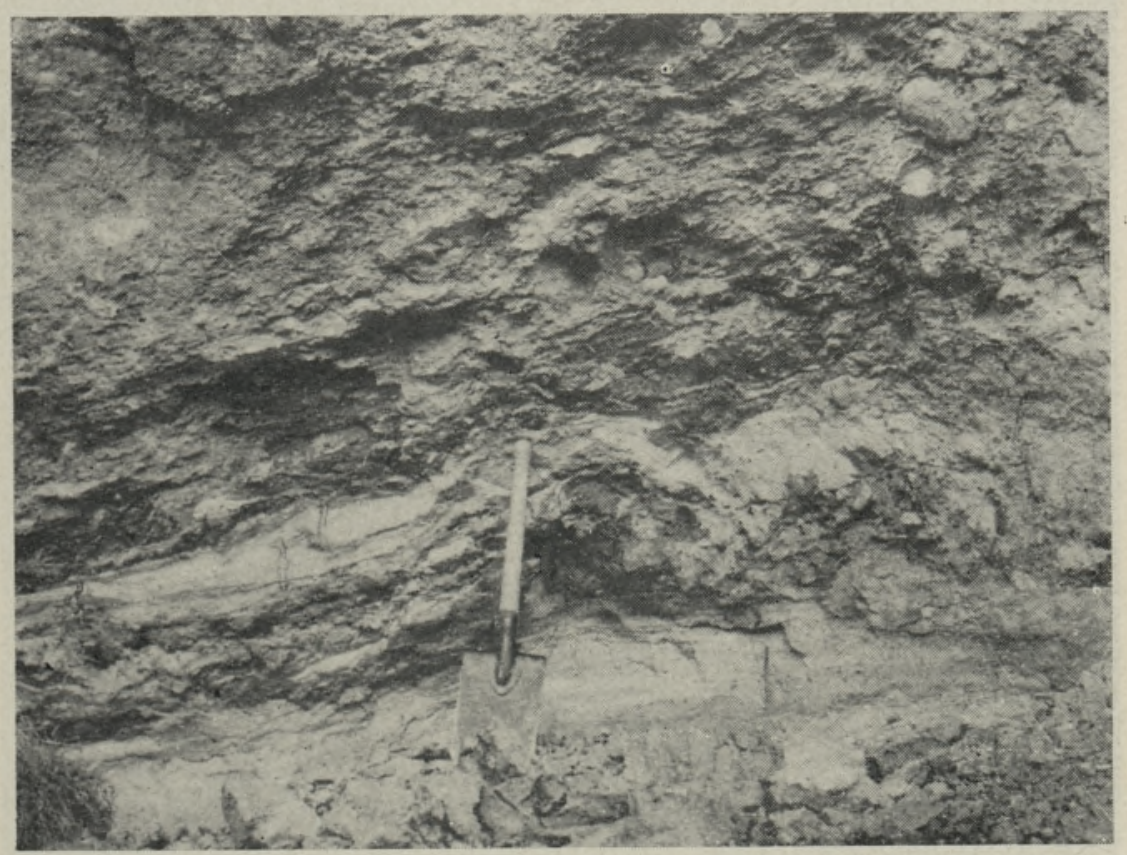

Рис. 3. Морена в Калана с тонким быстро выклинивающимся прослоем песка. Фото А. Мийдела. 


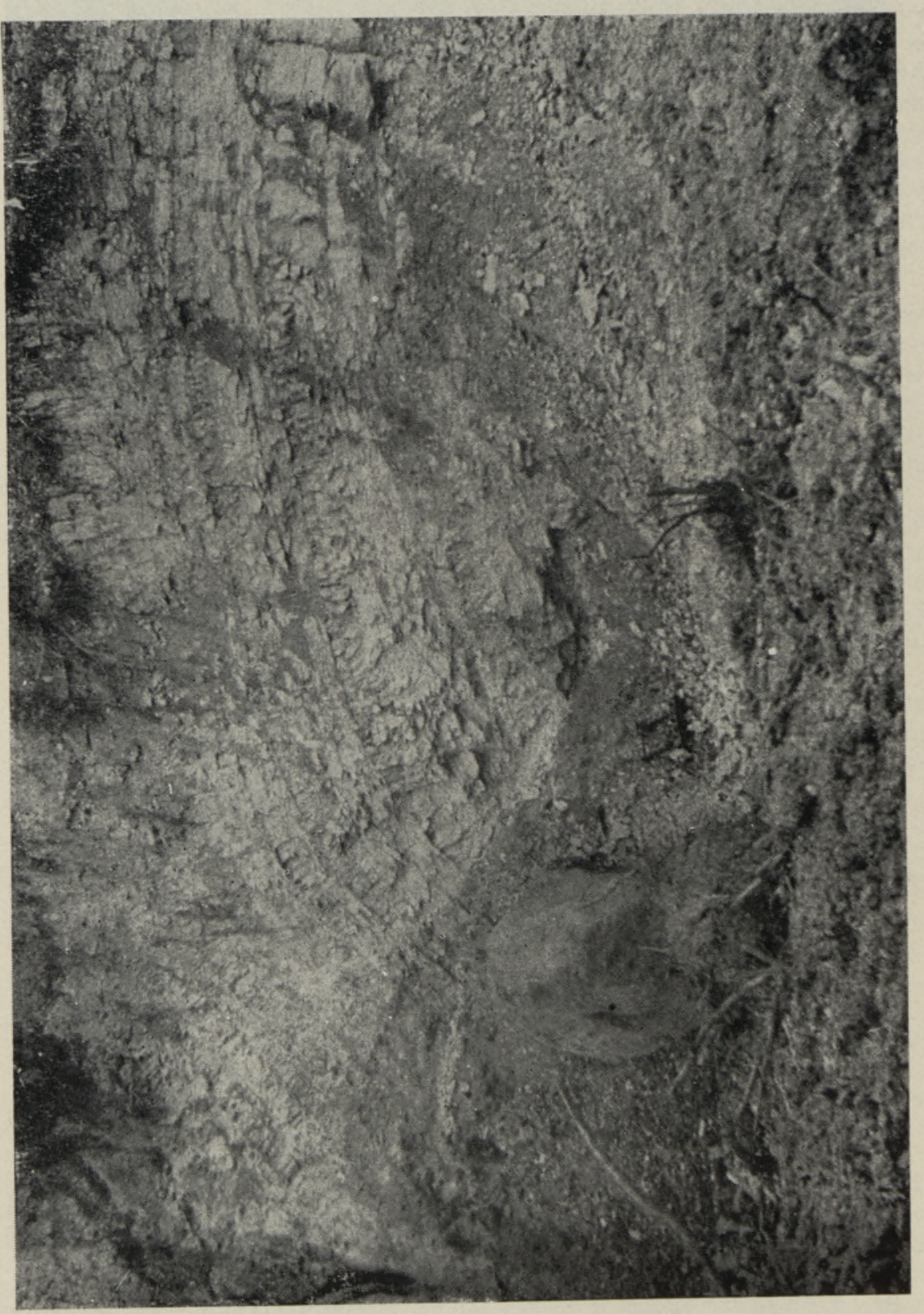

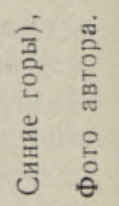

(x) 6.5.

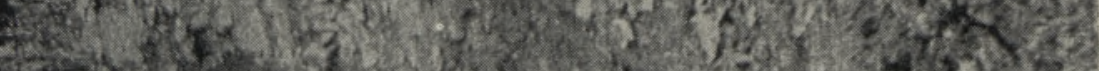

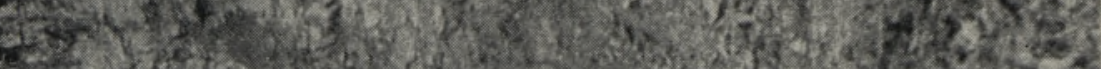

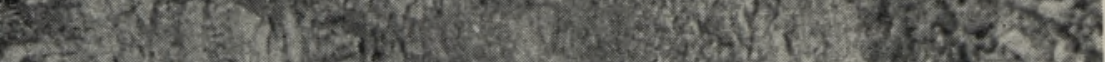

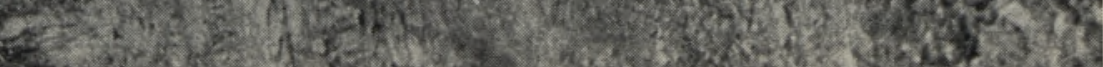

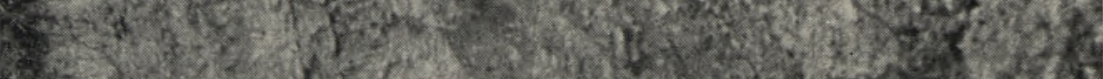

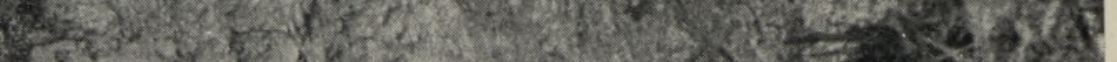

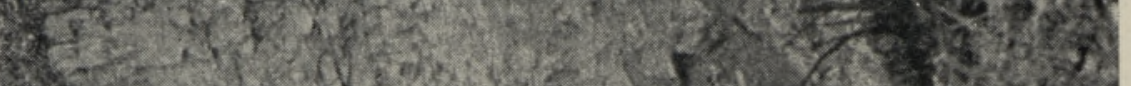

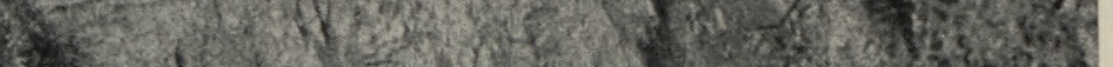

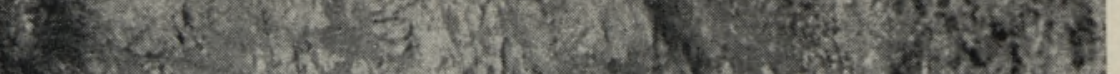

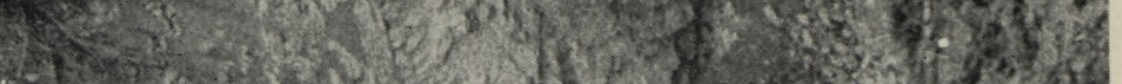

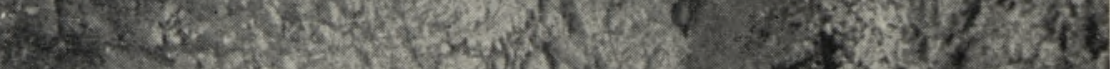

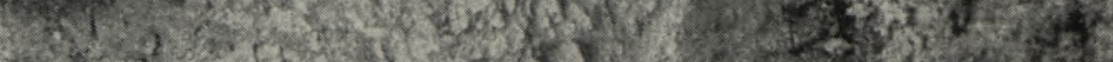

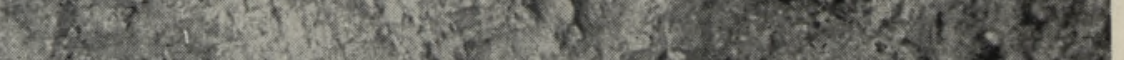

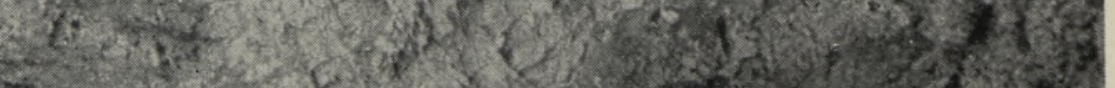

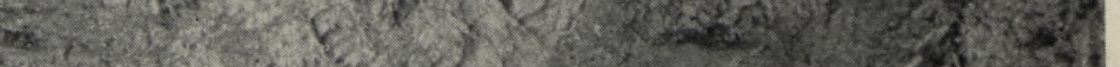

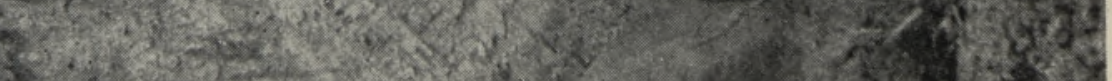

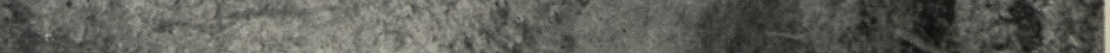
S. 1.

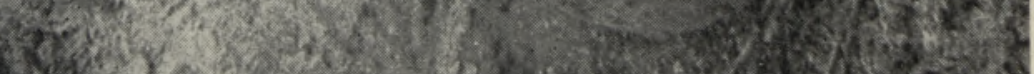

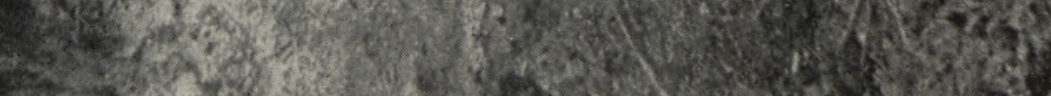

Oे 
Особо следует остановиться на гляциодинамических текстурах моренных отложений, которым в последние годы уделялось довольно много внимания (Virkkala, 1952; Repo, 1957; Dreimanis, 1962; Шанцер, 1966; Лаврушин, 1969, 1970а, б; Гайгалас, 1968, 1969 и др.) и которые, пожалуй, особенно четко говорят о субаэральном ледниковом генезисе моренных толщ. Динамическое воздействие ледника в моренах Эстонии обнаруживается прежде всего в разных видах сланцеватости, особенно ярко проявляющейся в глинистых разновидностях морены, содержащих в небольшом количестве грубообломочные фракции (рис. 2). В сланцеватых моренах наблюдаются микросбросы, складки и псевдонадвиговые текстуры. Местами обнаруживается даже вертикальная сланцеватость, возникающая при двустороннем боковом давлении (Гайгалас, 1968). В ряде случаев, например в Вылумяги (Раукас и др., 1971), можно наблюдать сланцеватую морену с признаками псевдослоистости, что является, вероятно, результатом частичной водной обработки моренного материала и неодинакового растаскивания подстилающих пород (Шанцер, 1966). В морских и ледово-морских отложениях, как известно, гляциодинамические текстуры не встречены.

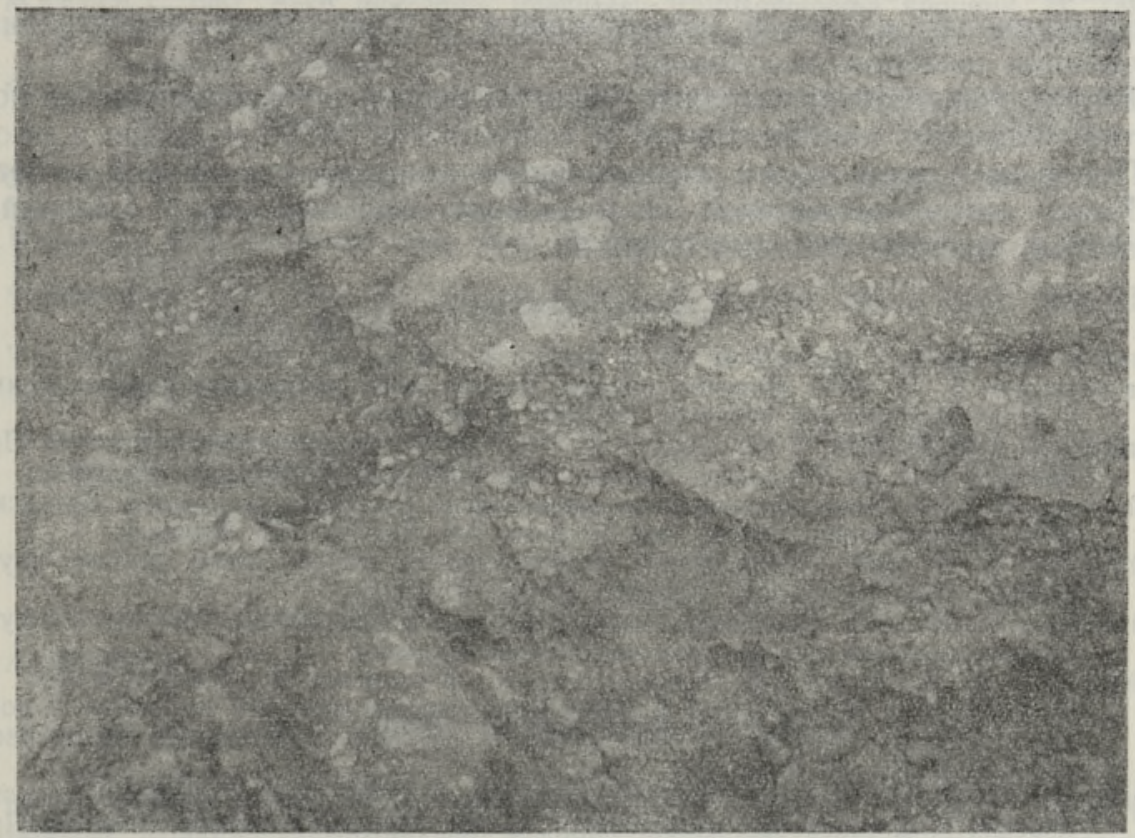

Рис. 5. Субаквально отложенная слоистая морена, переходящая в водно-ледниковые отложения. Реаствере.

Фото А. Мийдела.

Добавим к этому, что на всей, территории Эстонии распространены типичные ледниковые комплексы форм рельефа, в строении и расположении которых четко прослеживается деятельность ледника. Они образуют определенные краевые полосы, тесно связанные с различными этапами жизни ледника. Удалось также подтвердить совпадение направления друмлинов и радиальных форм ледникового рельефа с направлением ледниковых шрамов и преобладающей ориентировкой обломков в основной морене (Raukas, 1961; Раукас и др., 1971), что никак нельзя объяснить с гляциомаринистских позиций. 
Таким образом, приведенные материалы говорят о континентальном ледниковом генезисе морен и не дают повода для ревизни традиционной концепции материкового оледенения, по крайней мере, в отношении территории Эстонии, для которой совершенно неприемлема концепция гляшиомаринизма, вызвавшая в последние годы оживленные дискуссии. Вместе с тем нельзя и отрицать возможность широкого распространения ледово-морских условий в некоторых других районах СССР. Ледовоморские условия, несомненно, существовали также местами и на территории Эстонии, особенно на заключительных этапах отступания ледника, когда болышие ее участки были заняты крупными и характеризовавшимися значительной ледовитостью озерно-ледниковыми бассейнами. В последних безусловно могли появиться и айсберги, разносившие отдельные валуны по затопленным частям суши и отложившие местами (напр., на вершинах камов) маломошный покров морены. Такие моренные слои, как правило, характеризуются пониженным содержанием пелитовых частиц, малой уплотненностью и отсутствием столь типичной для основной морены ориентировки галек и валунов (рис. 5). Но ледово-морские условия и айсберговые морены отнюдь не отрицают ледниковой теории, а наоборот - говорят в пользу существования крупных континентальных ледниковых покровов, покрывавших в плейстоцене значительные терпитории северного полушария.

В заключение автор выражает благодарность за сотрудничество коллективу кафедры криолитологии и гляциологии МГУ во главе с проф. А. Поповым и всем лицам, выполнявшим анализы для данной работы. K. Каяку автор признателен за предоставление кернового материала некоторых опорных буровых скважин.

\section{ЛИТЕРАТ УРА}

А фан асьев Б. Л. 1967. Морские морены Латвии и их возможное корреляционное и стратиграфичегкое значение. Baltica, 3. Вильнюс.

А фан а сь е в Б. Л. 1968. О находках и значении фауны фораминифер в моренах Прибалтики. Мат-лы V конфер. геологов Прибалтики н Белоруссии. Вильнюс.

$\mathrm{B}$ и йдин н $\mathrm{X}$ 1957. Распространение и петрография эрратических валунов Эстонской CС. Научн. сообщ. Ин-та геол. и геогр. АН ЛитССР, IV. Внльнюс.

Г айга л а с А. И. 1968. Сланшеватость плейстощеновых морен Литвы. Мат-лы научн. конфер. молопых ученых геологов Литвы. Вильнюс.

Г а иे г л а с А. И. 1969. Слпистость плейстошеновых морен Литвы. Мат-лы II научн. конфер. молодых ученых геологов Литвы. Вильнюс.

Гайгалас А., Гуделис В., Спрингис К., Коншин Г., Савваитов А., В е йн бе ргс И., Р а ук а с А. 1967. Ориентировка длинных осей галек в моренах послепнего олеленения Прибалтики и ее связь с убыванием ледникового покрпва. Baltica, 3. Вильнюс.

Д анил лов И. Д., Н е дешев а Г. Н., С ми нов а П. И. 1968. К вопросу о ледовоморских плейстоненовых отложеннях Латвии. Мат-лы V конфер. геологов Прибалтики и Белоруссии. Вильнюс.

Л а в р ушин Ю. А. 1969. Четвертичные отложения Шпишбергена. М.

Л а в рушин Ю. А. 1970а. Отражение динамики движения ледника в строении донной мопены. Литология и полезные ископаемые. 1.

Л а в рушин Ю. А. 19706 . Опыт выделения фаций и субфаций в донной морене материкового оледенения. Литология и полезные ископаемые, 6.

Пи до п ли ч ко И. Г. 1946. О ледниковом периоде, вып. 1. Возникновение и развитие учения о ледниковом периоде. Кнев.

Пи допли и ко И. Г. 1951. О ледниковом периоде, вып. 2. Киев.

Пи до п ли ч ко И. Г. 1954. О ледниковом периоде, вып. 3. Киев.

Пи допл и и о И. Г. 1956. О ледниковом периоде, вып. 4. Происхождение валунных отложений. Киев.

Пи до п ли ч к о И. Г. 1963. Развитие теории антигляциализма в последние годы. В сб.: Природная обстановка и фауны прошлого, вып. 1. Киев.

Пи р р ус Э. 1968. Ленточные глины Эстонии. Таллин.

Р а ук а с А. 1962. Закономерности распределения галек в моренах Эстонии. Изв. АН ЭССР, Сер. физ.-матем. и техн. н., XI, № 2. 
Р аукас А. 1963. Распространение руководящих валунов в моренах последнего оледенения Эстонской ССР. Изв. АН ЭССР, Сер. физ.-матем. и техн. н., ХІІ, № 2.

$\mathrm{P}$ а ук а с А., Л и й в р анд Э. 1971. Плейстоценовые отложения в разрезе скважины Вяэна-Иыесуу (Северная Эстония) и их генезис. Изв. АН ЭССР, Хим. Геол., 20, № 1 .

Р а укас А. В.. Ряхни Э. Э., Мийдел А. М. 1971. Краевые ледниковые образо вания Северной Эстонии. Таллин.

Р ухина Е. В. 1960. Литология моренных отложений. Л.

С ереб рянны й Л. Р., Р а у а с А. В. 1970. Новые пути и методы изучения ледниковой истории Русгкой равнины в верхнем плейстоцене. Географ. сборник, 4. М.

Ч у в а д и н ски й В. Г. 1967. Вопросы формирования валунных отложений и рельефа на Кольском полуострове. В сб.: Природная обстановка и фауны прошлого. Киев.

Ш а н ц р Е. В. 1966. Очерки учения о генетических типах континентальных осадочных образований. Тр. Геол. ин-та АН СССР, вып. 161.

Dreiman is A. 1962. Deformational structures of glacial origin in ground moraine areas. The Royal Society of Canada. June Meeting, 1962. Programme of Papers.

Gre w in g k C. 1879. Erläuterungen zur zweiten Ausgabe der geognostischen Karte Liv-, Ehst- und Kurlands. Arch. Naturk. Liv-, Est- u. Kurl., Ser. 1, 8.

$\mathrm{He}$ in s a 1 u U. 1970. Aluspōhja glatsitektoonilisi lasumusrikkeid Kirde-Eestis. Eesti Loodus, Nr. 2.

J a a n o o n-Orviku K. 1926. Rändpangaseid Eestis. Loodusuurijate Seltsi aruanded, XXXIII, Nr. 7.

Martin L. 1967. Eesti moreenide tihedusest. Ehitusgeoloogia kogumik. II. Tallinn.

$\mathrm{Nug}$ is S. 1962. Lõuna-Eesti moreenide geotehnilistest omadustest. Ehitusgeoloogiline kogumik. I. Tallinn.

Orviku K. 1930. Die Glazialschollen von Kunda-Lammasmägi und Narva-Kolmistu (Eesti). Sitzungsberichte der Naturf. Ges. Univ. Tartu (Dorpat), XXXVI, Nr. $3 / 4$

Orviku K. 1936. Kihitussiirdeid Eesti aluspōhjas. Eesti Loodus, Nr. 2.

$\mathrm{R}$ a u k a s A. 1961. Mandrijää liikumisest Eestis. Eesti Loodus, Nr. 5.

$\mathrm{R}$ e p o R. 1957. Untersuchungen über die Bewegungen des Inlandeises in Nordkarelien. Helsinki.

S chmidt F. 1871. Uber die Glacialformation in Estland. Neues Jahrb. Mineral, Geol. u. Paläontol. Berlin.

Virkka la K. 1952. On the Bed Structure of Till in Eastern Finland. Bull. Comm. geol. de Finlande, No. 159.

\section{Ннститут геологии \\ Академии наук Эстонской ССР}

Поступила в редакцию 5/IV 1972

\section{A. RAUKAS}

\section{EESTI MOREENIDE GENEESIST}

Moreenide paleontoloogiline, geokeemiline, litoloogilis-mineraloogiline ja struktuurilis-tekstuuriline uurimine koos geomorfoloogiliste vaatlustega kinnitavad nende liustikutekkelist, valdavalt kontinentaalset päritolu. Moreenides hajusalt esinev merefauna on enamasti ümber settinud.

\section{A. RAUKAS}

\section{THE GENESIS OF ESTONIAN TILLS}

Palaeontological, geochemical, lithologico-mineralogical and structural-and-textural researches into Estonian tills, accompanied by gemorphological observations have revealed their glacial, mainly continental, origin. The marine fauna occasionally represented in the tills occurs in a redeposited state. 